\title{
CEMARAN BAKTERI DAN RESIDU PESTISIDA PADA BUAH ANGGUR
}

\author{
Ryan Suparman ${ }^{1)}$ Armita Athennia ${ }^{2)^{*}}$ \\ Program Studi S1 Gizi Universitas Mohammad Husni Thamrin
}

\begin{abstract}
ABSTRAK
Buah merupakan komoditas pangan yang banyak dikonsumsi oleh rumah tangga di Indonesia, baik dalam keadaan segar. Dikaitkan dengan masalah keamanan pangan, buah-buahan ini dapat dikatakan sebagai jenis buah yang berpeluang mengandung residu pestisida melebihi batas maksimum residu karena buah disemprot pestisida secara langsung selama proses produksi. Penelitian ini bertujuan untuk mengetahui keberadaan residu pestisida (golongan organofosfat) dan bakteri Escherichia coli pada buah anggur lokal dan Impor. Penelitian ini bersifat kuantitatif dengan desain penelitian survey observational. Sampel dalam penelitian ini adalah anggur impor dan lokal yang di beli pada 3 pedagang berbeda.Pengambilan sampel di Pasar Induk Kramat Jati. Hasil penelitian memperlihatkan bahwa keberadan Escherichia coli pada buah anggur lokal dan impor adalah <0,3 MPN/g dibawah standar nasional Indonesia dan ditemukan residu pestisida organofosfat pada buah anggur impor dan lokal namun kadarnya masih dalam batas aman.
\end{abstract}

Kata Kunci : Bakteri, Escherichia Coli, Residu Pestisida, Anggur, Buah

\section{PENDAHULUAN}

Buah merupakan sumber zat gizi mikro alami yang essensial bagi tubuh. Pentingnya konsumsi buah-buahan diserukan oleh Kementrian Kesehatan Indonesia sebagai salah satu upaya peningkatan kesehatan masyarakat dalam program Gerakan Masyarakat Hidup Sehat (GERMAS). Menurut Semarajaya (2013), terjadi peningkatan permintaan buah oleh konsumen setiap tahunnya sebesar 5\%. Adapun peningkatan konsumsi buah harus diikuti oleh pengawasan terhadap keamanan buah.

Peraturan Pemerintah (PP) Nomor 28 Tahun 2004 tentang Keamanan, Mutu dan Gizi Pangan menyebutkan bahwa keamanan pangan adalah kondisi dan upaya yang diperlukan untuk mencegah pangan dari kemungkinan cemaran biologis, kimia dan benda lain yang dapat mengganggu, merugikan dan membahayakan kesehatan manusia. Salah satu indikator keamanan produk buah ialah residu pestisida dan cemaran mikroba.

Penggunaan pestisida merupakan alternatif dalam mengandalikan cemaran hama dan penyakit tanaman buah. Peningkatan penggunaan bahan kimia pestisida telah menimbulkan kecemasan dikalangan masyarakat luas karena terbukti bahwa pestisida dapat menimbulkan dampak negatif pada manusia (Agustina, 2015). Adanya residu pestisida dalam makanan, termasuk dalam sayur dan buah merupakanmasalah utama bagi kesehatan masyarakat. Residu yang sampai kepada manusia dapat ditinggalkan secara langsung maupun tidak langsung. Makanan yang mengandung residu pestisida jika dikonsumsi dalam jangka panjang akan menimbulkan gangguan kesehatan yang ditunjukkan dengan adanya gejala akut seperti sakit kepala, mual, dan muntah serta gejala kronis seperti kehilangan nafsu makan, kejang otot, dan lain-lain (Yuantari, 2015). Di Indonesia pestisida sintetik yang banyak digunakan oleh petani adalah golongan organofosfat (Prijanto, 2009). Menurut laporan WHO, terdapat 26 juta kasus keracunan residu pestisida dan angka kematian mencapai 220 ribu kasus per tahunnya. Data Badan POM tahun 2017, kasus keracunan akibat residu pestisida yang berlebih mencapai 433 kasus. 
Cemaran mikroba pada buah dapat disebabkan oleh proses penyemprotan dan pengairan yang terkontaminasi oleh mikroba serta pemupukan dengan kotoran hewan. Cemaran bakteri Escherichia coli biasanya berasal dari tinja manusia atau hewan (Harsojo dan June, 2009). SNI untuk Buah segar mensyaratkan bahwa cemaran bakteri/mikroba maksimum untuk Angka Paling Mungkin (Most Probable Number/MPN) Escherichia coli $<20 / g$ (BSN, 2009). Escherichia coli merupakan beberapa jenis bakteri patogen yang membahayakan kesehatan manusia. Lebih dari 90\% terjadinya foodborne disease pada manusia disebabkan kontaminasi mikrobiologi. World Health Organization mendefinisikan foodborne diseases sebagai penyakit yang umumnya bersifat infeksi atau racun yang masuk ke dalam tubuh melalui makanan yang dicerna (Harsojo dan June, 2009).

Anggur dinyatakan sebagai buah yang rawan memiliki residu pestisida tinggi. Anggur berkulit tipis dan lunak sehingga rentan terserang ngengat dan hama. Sehingga penggunaan pestisida oleh petani pada buah anggur cenderung lebih banyak. Selain itu, potensi memar pada anggur yang tinggi menyebabkan bakteri dapat dengan mudah tumbuh. Anggur merupakan tanaman asli Eropa dan Asia Tengah yang banyak diminati oleh masyarakat Indonesia. Hal ini dapat dilihat dari peringkat anggur sebagai buah yang paling banyak diimpor setelah apel, jeruk, pir, dan kurma (Anonim, 2012).

Tujuan penelitian ini adalah untuk mengetahui jumlah bakteri Escherichia coli dan kadar residu pestisida jenis organofosfat pada buah anggur.

\section{METODE PENELITIAN}

Sampel penelitian ini adalah buah anggur impor dan lokal yang dibeli dari pedagang buah eceran di sekitar Pasar Induk Kramat Jati, Jakarta. Metode pemilihan pedagang buah dilakukan secara acak (random sampling). Dari masing-masing pedagang didapatkan 3 buah sampel anggur anggur impor dan lokal. Sampel buah yang akan dianalisis masing-masing akan ditempatkan pada kantong plastik bersih dan tertutup kemudian dibawa menggunakan kotak pendingin. Penelitian ini dilakukan pada bulan Juli - September 2019.

Analisa aktivitas bakteri Escherichia coli dilakukan oleh PT. Saraswanti Indo Genetech dengan metode Most probably Number (MPN) yaitu jumlah perkiraan terdekat. Tahap analisis terdiri dari uji perkiraan, uji penegasan, dan uji pelengkap (SNI, 2008).

Analisa residu pestisida dilakukan oleh Laboratorium pengujian Balai Besar Penelitian dan Pengembangan Pasca Panen Pertanian dengan metode Gas Chromatography (GC) menurut AOAC (1990). Pestisida yang diteliti adalah golongan organofosfat. Tahap analisis meliputi ekstraksi bahan buah, pembuatan larutan standar dan analisis kuantitatif (perhitungan kadar residu). Recovery test merupakan patokan untuk menilai apakah metode yang digunakan sudah cukup baik (Marsun, 2014).

Variabel yang diteliti pada penelitian ini adalah aktivitas bakteri Escherichia coli dan kadar residu pestisida organofosfat dalam buah anggur impor dan lokal. Adanya aktivitas bakteri Escherichia coli akan dibandingkan dengan Batas Maksimum Cemaran Mikroba dalam bahan pangan (SNI 7388:2009) dan untuk kadar residu pestisida pada sampel akan dibandingkan dengan Batas Maksimum Residu Pestisida pada hasil pertanian (SNI 7313:2008) 


\section{HASIL \& PEMBAHASAN}

Tabel 1.

Hasil Analisis Keberadaan Bakteri Escherichia Coli pada Buah Anggur Lokal dan Impor

\begin{tabular}{ccc}
\hline \multirow{2}{*}{ Sumber Sampel } & \multicolumn{2}{c}{$\begin{array}{c}\text { Cemaran Bakteri Escherichia Coli } \\
\text { (MPN/g) }\end{array}$} \\
\cline { 2 - 3 } & Anggur Lokal & Anggur Impor \\
\hline Pedagang A & $<0,3$ & $<0,3$ \\
\hline Pedagang B & $<0,3$ & $<0,3$ \\
\hline Pedagang C & $<0,3$ & $<0,3$ \\
\hline
\end{tabular}

Hasil analisa keberadaan bakteri Escherichia coli pada buah Anggur lokal dan anggur impor pada tiga pedagang berbeda menununjukan buah anggur lokal maupun impor terdeteksi mengandung bakteri Escherichia coli sebanyak $<0,3 \mathrm{MPN} / \mathrm{g}$.

Tabel 2.

Hasil Analisis Residu Pestisida pada Buah Anggur Lokal dan Impor

\begin{tabular}{llcc}
\hline \multicolumn{1}{c}{ Sumber sampel } & \multicolumn{1}{c}{$\begin{array}{c}\text { Pestisida } \\
\text { Organofosfat }\end{array}$} & Kadar Pestisida (ppm) \\
\cline { 2 - 4 } Pedagang A & Diazinon & 0,024 & Anggur Impor \\
\cline { 2 - 4 } & Malation & 0,092 & 0,021 \\
\cline { 2 - 4 } & Profenofos & Ttd & 0,066 \\
\hline Pedagang B & Diazinon & 0,022 & 0,085 \\
\cline { 2 - 4 } & Malation & 0,092 & 0,022 \\
\cline { 2 - 4 } Pedagang C & Profenofos & 0,119 & 0,105 \\
& Diazinon & 0,021 & 0,024 \\
\cline { 2 - 4 } & Malation & 0,067 & 0,079 \\
\cline { 2 - 4 } & Profenofos & 0,091 & $\mathrm{ttd}$ \\
\hline
\end{tabular}

Keterangan $: \mathrm{ttd}=$ tidak terdeteksi

Berdasarkan hasil pemeriksaan kandungan residu pestisida organofosfat pada buah anggur lokal dan anggur impor pada tiga pedagang berbeda menunjukan, pada Pedagang A terdeteksi residu pestisida organofosfat dengan bahan aktif diazinon, malation dan profenos untuk anggur lokal 0,024 ppm dan malation 0,092 ppm, tetapi profenos tidak terdeteksi, untuk buah anggur impor terdeteksi bahan aktif diazinon sebanyak 0,021 ppm, malation 0,066 ppm dan profenofos 0,085 ppm. Pedagang B terdeteksi bahan aktif residu pestisida organofosfat diazinon malation untuk buah yang lokal diazinon sebanyak 0,022 ppm. dan malation 0,092 ppm dan profenofos $0,119 \mathrm{ppm}$, sedangkan untuk buah anggur impor diazinon $0,022 \mathrm{ppm}$, malation $0,088 \mathrm{ppm}$ dan profenofos 0,105 ppm. Pedagang $\mathrm{C}$ terdeteksi residu pestisida organofosfat dengan bahan aktif diazinon dan malation, untuk buah anggu lokal diazinon sebanyak 0,021 ppm, malation sebanyak 0,067 ppm dan profenofos sebanyak 0,091ppm, sedangkan buah anggur impor diazinon sebanyak 0,024 ppm, malation sebanyak 0,079 ppm sedangkan profenofos tidak terdeteksi.

Pengujian cemaran mikroba pada buah anggur lokal dan impor pada tiga pedagang berbeda terdeteksi mengandung bakteri Escherichia coli sebanyak <0,3 MPN/g. Hasil tersebut menandakan buah anggur lokal dan 
impor terdeteksi bakteri Escherichia coli tetapi jumlahnya masih berada dalam batas maksimum cemaran Escherich ia coli menurut SNI yaitu, $<20 \mathrm{MPN} / \mathrm{g}$.

Buah dan sayur dapat tercemar oleh bakteri pathogen dan air irigasi yang tercemar limbah, tanah, atau kotoran hewan yang digunakan sebagai pupuk. Cemaran akan semakin tinggi pada bagian tanaman yang ada di dalam anah atau dekat dengan tanah. Mikroba tertentu seperti Liver fluke dan Fasciola hepatica akan berpindah dari tanah ke tanaman akibat penggunaan kotoran kambing atau domba yang tercemar sebagai pupuk. Air irigasi yang tercemar Shigella sp., Salmonella sp., Esherichia coli dan Vibrio cholera dapat mencemari buah dan sayur. Selain itu, bakteri bacillus sp., Clostridium sp., dan Listeria monocytogenes dapat mencemari buah dan sayur melalui tanah. (Atmiati , 2012).

Foodborne disease merupakan penyakit yang diakibatkan karena mengkonsumsi makanan yang dapat tercemar mikroba pathogen. Lebih dari $90 \%$ kejadian penyakit pada manusia disebabkan mengkonsumsi makanan yang tercemar bakteri pathogen, seperti penyakit tipus, disentri, botulisme, dan intoksikasi bakteri lainnya seperti hepatitis A (Newell. 2010).

Mikroba terutama bakteri yang bersifat patogen dapat ditemukan di mana saja, yaitu di tanah, udara,tanaman, binatang, bahan pangan, peralatan untuk pengolahan bahkan pada tubuh manusia. Pangan membawa ber bagai jenis mikroba, yang dapat berasal dari mikroflora alami tanaman atau hewan, baik yang berasal dari lingkungan maupun yang masuk selama pemanenan atau pemeliharaan, distribusi, penanganan pascapanen, pengolahan, serta penyimpanan produk.

Saluran pencernaan manusia merupakan sistem yang terbuka, apabila mikroba pathogen mengkontaminasi suatu bahan pangan lalu dikonsumsi oleh manusia maka dapat menyebabkan kesakitan. Racun atau toksin yang dihasilkan oleh mikroba patogen yang dikonsumsi dapat menyebabkan gejala penyakit yang disebut keracunan atau intoksikasi. Gejala akut yang disebabkan oleh mikroba patogen antara lain diare, muntah dan pusing bahkan pada kondisi yang parah dapat menyebabkan kematian (Kirk, 2015).

Pengujian residu pestisida pada sampel menunjukan adanya residu pestisida yang masih terdeteksi pada buah anggur baik lokal maupun impor. Pada sampel anggur lokal pedagang A terdeteksi residu pestisida organofosfat dengan bahan aktif diazinon dan malation dengan masing masing kadar 0,024 ppm dan 0,092 ppm. Adapun kadar residu pestisida tersebut masih di bawah batas maksimum yang ditetapkan dalam SNI 7313:2008, yaitu pada diazinon 0,5 ppm; malation $2 \mathrm{ppm}$; dan profenofos 0,5 ppm Sedangkan pada buah anggur impor terdeteksi residu pestisida organofosfat diazinon, malation, dan profenofos masing-masing sebanyak 0,021 ppm, 0,066 ppm dan 0,085 ppm. Kadar tersebut juga masih berada dibawah batas maksimum yang telah ditetapkan. Pedagang B pada buah anggur lokal terdeteksi bahan aktif residu pestisida organofosfat diazinon sebanyak 0,022 ppm, malation 0,092 ppm dan profenofos 0,119 ppm, sedangkan untuk buah anggur impor diazinon 0,022 ppm, malation 0,088 ppm dan profenofos 0,105 ppm. Baik dari buah anggur lokal dan anggur impor masih berada dibawah batas minimum yang ditetapkan.

Pedagang $\mathrm{C}$ pada buah anggur lokal terdeteksi residu pestisida organofosfat dengan bahan aktif diazinon sebanyak 0,021 ppm, malation sebanyak 0,067 ppm dan profenofos sebanyak 0,091 ppm, sedangkan buah anggur impor diazinon sebanyak $0,024 \mathrm{ppm}$, malation sebanyak 0,079 ppm sedangkan profenofos tidak 
terdeteksi. Baik dari buah anggur lokal dan anggur impor masih berada dibawah batas minimum yang ditetapkan.

Pestisida merupakan pilihan utama dalam pengendalian hama, penyakit, dan gulma karena membunuh langsung jasad pengganggu. Di Indonesia pestisida sintetik yang banyak digunakan oleh petani adalah golongan organofosfat. Pestisida golongan organofosfat banyak digunakan karena memiliki sifat yang menguntungkan seperti tidak presisten dalam tanah, selektif, dan tidak menyebabkan resistensi pada serangga. Masa penyemprotan pestisida golongan organofosfat dilakukan dalam dua minggu sekali karenak masa degradasi organofosfat dalam lingkungan adalah sekitar dua minggu (Djojosumarto, 2008). Beberapa penelitian telah dilakukan untuk mendegrradasi residu pestisida pada buah dan sayuran. Menurut Alen, dkk (2015), penurunan jumlah residu pestisida dipengaruhi oleh beberapa faktor, yaitu daya larut, hidrolisis, penguapan, perlakuan mekanis dan fisik, dan kimiawi. Proses pencucian dengan air dan dengan deterjen pencuci buah signifikan menurukan residu pestisida (Munarso, 2016). Oleh karena itu, dimungkinkan kandungan pestisida pada sampel sudah menguap dan berkurang kadarnya dari saat proses panen dan sampai ke pedagang buah ecer. Proses pencucian yang mungkin dilakukan oleh pedagang atau pomasok juga dapat mempengaruhi kadar residu pestisida pada sampel.

Senyawa organofosfat mempengaruhi sistem saraf dan menghambat kerja enzim asetilkolenesterase sehingga asetilkolin tidak terhidrolisis. Enzim asetilkonesterase secara normal menghidrolisis asetilkolin menjadi asetat dan kolin. Pada saat enzim dihambat, mengakibatkan jumlah asetilkolin meningkat dan berkaitan dengan reseptor muskarinik dan nikotinik pada system saraf pusat dan penifer. Hal tersebut menyebabkan timbulnya gejala keracunan pada seluruh bagian tubuh. Jika aktifitas enzim asetilkolinesterase turun atau berkurang karena adanya pestisida organofosfat dalam darah yang akan membentuk senyawa phosphorylated cholinesterase, sehingga enzim tersebut tidak dapat berfungsi lagi. Dampak terhadap konsumen umumnya berbentuk keracunan kronis yang tidak langsung dirasakan. Namun, dalam waktu lama bias menimbulkan gangguan kesehatan seperti gangguan terhadap saraf, hati, perut, system kekebalan, dan hormon. Gejala keracunan ini baru kelihatan setelah beberapa bulan atau beberapa tahun kemudian (Widyawati, 2018).

\section{KESIMPULAN}

Jumlah bakteri Escherichia coli pada sampel buah anggur lokal dan impor masih berada pada batas aman. Adapun masih ditemukannya residu pestisida golongan organofosfat dengan bahan aktif diazinon, malation, dan profenofos pada sampel buah anggur lokal maupun impor. Namun kadar residu yang ada masih jauh di bawah batas maksimum residu pestisida. Dengan demikian dapat disimpulkan bahwa buah anggur lokal dan impor yang dijual di pedagang eceran tergolong aman menurut SNI 7313:2008. Perlu dilakukan penelitian lanjutan untuk melengkapi kemungkinan adanya cemaran bakteri dan kimia lain pada buah-buahan yang ada di pasaran. 


\section{REFERENSI}

1. Agustina, G. T., Triani, I. L., \& Mulyani, S. (2015). Pengaruh Waktu Penyemprotan Terakhir Sebelum Panen Terhadap Residu Profenofos dan Karakteristik Sensoris Kubis (Brasicca oleracea var capitata). JURNAL REKAYASA DAN MANAJEMEN AGROINDUSTRI, 4(1), 1-10.

2. Alen, Y., Zulhidayati, Z., \& Suharti, N. (2015). Pemeriksaan residu pestisida profenofos pada selada (Lactuca sativa L.) dengan metode kromatografi gas. JSFK (Jurnal Sains Farmasi \& Klinis), 1(2), 140149.

3. Anonim. (2012). Healthy Articles: Sumber Bahaya dalam Bahan Pangan dan Cara Menghindarinya.

4. Atmiati, W. D. (2012). Faktor Faktor yang Berhubungan dengan Keberadaan Bakteri Escherichia Coli pada Jajanan Es Buah yang Dijual di Sekitar Pusat Kota Temanggung. Jurnal Kesehatan Masyarakat Universitas Diponegoro, 1(2).

5. Budi Prijanto, (2009). Analisis Faktor Risiko Keracunan Pestisida Organofosfat pada Keluarga Petani Hortikultura di Kecamatan Ngablak Kabupaten Magelang (Doctoral dissertation, Program Pasca Sarjana Universitas Diponegoro).

6. Djojosumarto, P. (2008) Tehnik Aplikasi Pestisida Pertanian. Jakarta: PT. Agromedia Pustaka .

7. Harsojo dan June, M. (2009). Uji Kandungan Mineral dan Cemaran Bakteri Pada Sayuran Segar Organik Dan Non Organik. Indonesia Chemical 9(2): 226-230.

8. Indonesia, S. N. (2008). Metode Pengujian Cemaran Mikroba dalam Daging, Telur dan Susu, Serta Hasil Olahannya. SNI, 2897, 2008.

9. Kirk, M. D., Pires, S. M., Black, R. E., Caipo, M., Crump, J. A., Devleesschauwer, B.,\& Hall, A. J. (2015). World Health Organization estimates of the global and regional disease burden of 22 foodborne bacterial, protozoal, and viral diseases, 2010: a data synthesis. PLoS medicine, 12(12), e1001921.

10. Marsun, I.F. (2014). Analisis residu pestisida pada tomat buah dan tomat sayur pada pasar swalayan di Kota Makassar 2014. Skripsi. Universitas Islam Negeri Alauddin. Makassar.

11. Munarso, S. J., \& Broto, W. (2016). Studi Kandungan Residu Pestisida pada Kubis, Tomat dan Wortel Di Malang dan Cianjur. Buletin Teknologi Pasca Panen, 5(1), 27-32.

12. Newell, D. G., Koopmans, M., Verhoef, L., Duizer, E., Aidara-Kane, A., Sprong, H., ... \& van der Giessen, J. (2010). Food-borne diseases - the challenges of 20 years ago still persist while new ones continue to emerge. International journal of food microbiology, 139, S3-S15.

13. Peraturan Pemerintah (PP) Nomor 28 Tahun 2004 : Keamanan, Mutu dan Gizi Pangan

14. Semarajaya, C. G. A. (2013). Penanganan Pasca Panen Buah-buahan. Fakultas Pertanian Universitas Udayana (UNUD).

15. Standar Nasional Indonesia. (2008). Batas Maksimum Residu Pestisida pada Produk Pertanian.

16. Standar Nasional Indonesia (2009). Batas Maksimum Cemaran Mikroba dalam Pangan.

17. WHO. (2005). Penyakit Bawaan Makanan. Fokus Pendidikan Kesehatan. Jakarta :ECG

18. WHO, 2015.Word health Organization. [Online] Available at: http://www.who.int/mediacentre/factsheets/f3399/en/. [Accesed 26 September 2019].

19. Widyawati, S. A., Siswanto, Y., \& Pranowowati, P. (2018). Potensi Paparan Pestisida Dan Dampak Pada Kesehatan Reproduksi Wanita Tani Studi Di Kabupaten Brebes. Jurnal Ilmu Keperawatan Maternitas, 1(1), 31-38.

20. Yuantari, M. G. C., Widianarko, B., \& Sunoko, H. R. (2015). Analisis Risiko Pajanan Pestisida Terhadap Kesehatan Petani. KEMAS: Jurnal Kesehatan Masyarakat, 10(2), 239-245. 